\title{
HISTORY
}

\section{ABOUT THE HISTORY OF DEVELOPMENT OF PUBLISHING INDUSTRY IN KARAKALPAKSTAN}

\author{
Idrisov Rashid Baysovich, (PhD) doctorateof NSPI.Nukus. Karakalpakstan.
}

DOI: https://doi.org/10.31435/rsglobal_wos/30122019/6845

\section{ARTICLE INFO}

Received: 28 October 2019

Accepted: 14 December 2019

Published: 30 December 2019

\section{KEYWORDS}

lithography, publishing, typesetting machines, Arabian graphics, course books, preparing personnels. \begin{abstract}
The article deals with the issues on the history of formation of publishing houses in Karakalpakstan at the first half of the XX century. The first typographic equipment in the region appeared at the end of the 19th century. During the Soviet period publication policy became an important part of the Soviet policy. The government financed this branch totally and provided the edition of book production includingthe books in the karakalpak language. In the 1930s the system of publishing industry which is completely controlled by the Centre was created in Karakalpakstan.
\end{abstract}

Citation: Idrisov Rashid Baysovich. (2019) About the History of Development of Publishing Industry in Karakalpakstan. International Academy Journal Web of Scholar. 12(42). doi: 10.31435/rsglobal_wos/30122019/6845

Copyright: (C) 2019 Idrisov Rashid Baysovich. This is an open-access article distributed under the terms of the Creative Commons Attribution License (CC BY). The use, distribution or reproduction in other forums is permitted, provided the original author(s) or licensor are credited and that the original publication in this journal is cited, in accordance with accepted academic practice. No use, distribution or reproduction is permitted which does not comply with these terms.

Introduction. As any industrial spheres the publishing sphere has its own history of development. In the presented article we'd like to write about the publishing industry in the example of Karakalpakstan. The appearance of publishing business began in the region with the coming of poligraphy and publication techniques, like offset printing. Offset printing was a German lithographic style which was implemented into the industry in the XIX century by Johann Zennefelder. Later it was used by many countries of the world and influenced on the development of this sphere.

The history of publication. The history of publication in Karakalpakstan began from the end of the XIX century, when in 1874 Khiva Khan Seyd Mukhammed Rakhim-khan II - Feruz brought the first printing machine to Central Asia. He appointed Atajan Abdalov responsible for the publishing, who with the help of his teacher Ibrakhim Sultan began to print the first books in lithographic way (Abduazizova, 2008: 12). They published mostly the historic works, and also the creations of Munis, Agakhiy, Bayoniy, Niyoziy and other poets-laureates of Khiva khanate.

Unfortunately, this industry had to stop his activity for some time because of poor financing. In 1893 Atajan Abdalov reestablished the publishing house again after buying typographic machines for his own money (200 roubles). And his name was recognized in the region, on the right bank of the Amudarya as "Atajan typist". His books became popular among local people, parts of which were kept in the libraries of mosques and madrasahs of the region (Semenov, 1971). We consider that some of the books, printed by Atajan typist came to mosques and madrasahs of the Karakalpakstan too, as they had a rich fund of publications. The researchers say that most publication products came to the territory of Karakalpakstan from abroad by merchants, and typographic machines were bought from Russia and Iran. (Nurjanov, 2015: 11).

This kind of situation was typical in this sphere, as it was only in its organizational stage at that time. So, at the beginning of 1920 there established the State Publication Center in Moscow, and in May 1924 - the Central Publication House - the biggest publication house, which published books 
in all languages of the people in the Union of the Soviet Socialist Republics. In order to improve the printing of books and apply printing houses with necessary materials there decided to unite the State Publication Center and some specialized offices. Centralization of organizations continued till the 1929. On December 28, 1928 the Central Committee of the All Union Communistic Party adopted a decree "On Providing people with books", where pointed that the literature for a mass should be a tool in the organization of a mass and in communistic enlightenment. This decision gave a great impulse to the improvement of publishing industry in the country and in Karakalpakstan. There given financial support to periphery printing houses to improve their financial situation, to prepare personnel, to involve qualified specialists, authors and editors. Several months before this decree, in autumn of 1928 the Presidium of the Executive Committee of the Karakalpak Autonomous Republic had adopted a decision "On organization of the Publishing Industry in Karakalpakstan". There stated that the only printing house was situated in Turtkul, which published only one newspaper "Independent karakalpak" and brochures and agitprop leaflets in small edition, but educational books were published in Tashkent and Moscow till the 1930s.

The archival sources let us think that the first printing machines were brought to the right bank of the river, which was ruled by the Russians, at the beginning of the XX century. In Amydarya district there worked a private printing house, the owner of which was somebody by name Nozikov. But after the soviet union had established his power the printing industry was under the regulation of the government, as this sphere was considered the most important aspect. Nozikov's publishing house in Amydarya region was taken by the government and other publishing houses in the left bank of the river were bankrupted. (Syinov,1964). A great number of books in kazakh were published in Karakalpakstan at that time. As the researcher O.Yusupov mentioned "during the twentieth years a lot of course books and literary books published in Orenburg, Kizilorda and Tashkent were spread in Karakalpakstan". In 1925 there were published the first three course books "Alippe (ABC)", "Reading book in the Karakalpak language", "Educating Adults" in the Eastern part of Kazakh State Publication. (Dosumov, 1960; Shalekenov, 1960; Syinov, 1962).

The First Books. After some time with great difficulties publishing houses began their activities. According to sources they printed only political literature, leaflets, small format newspapers (Yusupov,1993: 15-16). But most of the books for local people were brought from other places and all of them were in kazakh. A famous karakalpak scholar K.Ayimbetov wrote "At previous times we were lack of books and even pencils". Then we afforded each student have their own coursebooks. Kazakh eposes "Kiz Jibek", "Alpamis", "Kobilandi" and many other literary books published by Abubakir Divaev were sold in Chimbay by tatar tradesmen.We bought these books and read them with great interest. These books made great influence on our enlightenment" (Ayimbetov, 2008: 71). It is worth mentioning that at that time in karakalpak schools most subjects were conducted in kazakh, Kazakh language and literature were taught as a special subject in every school. According to K.Ayimbetov a lot of teachers from Kazakhstan came to the region before 1924. One of them Hilal (Ilal) Baymuhanbetov, about whom there were written "Hilal (Ilal) Baymuhanbetov together with Janahmat Akmanbetov came to Chimbay from Kizilorda and taught us. In 1925 Janahmat Akmanbetov returned to Kizilorda and Hilal became the head of Tortkul pedagogical college and taught Kazakh language and literature. At that time the native language was taught in Kazakh. Hilal Baymuhanbetov was 22 when he taught us, but his nature, character and teacher presence had a great influence on my becoming a person" (Ayimbetov, 2008:108).

In 1924 the Karakalpak Autonomous Region became in the Kazakh ASSR A.Dosnazarov paid great attention to publishing industry. In 1924-1925 he wrote letters to Kazakh soviet party organisations about the necessity of development and improvement of books and publication process (Nurjanov, 2015: 11). Kazakhstan government took his applications into account and asked the authorities in Moscow to budgeting the publishing industry of Karakalpak Autonomous Region. As a result the Center financial loan to the reestablishment of printing industry in Tortkul and in 1925-1926 the professional typist Atajan Abdalov leaded the work. (Syinov,1964). For some time the printing house had some challenges because of qualified personnel, lack of paper, paints and over use of printing types. Later all karakalpak and Kazakh intelligent people did all their best to the development of printing newspapers and books. We can mention their names as Kasim Auezov, Abu Kudabaev, Seyfulgabit Majitov, Seyitkali Agaydarov, Murtaza Baymenshin, Kenje Nazaralin, Tamendar Safiev and others.

The development of Karakalpak publishing industry was in close relation to the work of P. Varlamov who was appointed by Kazakh regional committee the secretary of local communistic 
party in 1927. Up to that time he worked as head of department on agitation and propaganda in Kazakh regional committee. At this time Kazakh government paid attention to the publishing houses and there given financial support to these houses.

In 1928 on December 28 a Legislation act of Central Committee of Communistic Party "On servicing the public with books" was adopted. This legislation pointed the importance of folk literature as a tool for enlightening the people and uniting the society (http://coolreferat.com/). A bit earlier, especially in autumn of 1928 according to the decision of the Presidium of the Karakalpak Autonomous Region "the organization of Publishing process in Karakalpakstan" was discussed and there mentioned the slow development of the industry because of limited fundling. The only Publishing house was in Tortkul at that time and it only published leaflets and brochures. Most of political books, brochures, business blanks were brought from publishing houses of other cities. Later local intelligence like Seyfulgabit Majitov and Kasim Awezov wrote books which were published in Moscow and Tashkent till $1930^{\text {th }}$.

In 1930 a huge polygraph enterprise - Union of printing books and magazines was organized in Moscow. This was the first step to centralize the publishing industry, as there were involved 30 different publishing houses, a number of great printing stores, specialized educational and scientific establishments, and there organized a special department on bookselling.

Government Policy. On August 15, 1931 the Central Committee of the Communistic Party adopted a decree "On Publication Affairs" according to which several Publishing houses were separated from the Union of State Publications; and publishing houses in all the republics of the Soviet Union were given a function to print books in the languages of nations in the USSR. After entering the poligraphy sphere of the Russian Federal Soviet Socialist Republic, the karakalpak poligrapy began to develop; there organized the Karakalpak Publishing house of books and magazines, the local printing houses were reequipped, qualified personnel were involved into the work and new types in Latin graphics were bought. The main polygraph machines factory was in Leningrad, factory named after Max Heltz, which constructed the interlinear machines -linotypes. In 1933 the factory sent printing machines «Linotype» и «Sinkografiya» and in 1934 two more printing equipment "Pioneer" to Karakalpakstan (QzilQaraqalpaqьstan, 1935)

So, from 1930s there began the formation and the development of publishing industry in Karakalpakstan. Together with the improvement of the financial and technical condition of the Karakalpak Publishing House, there also involved young personnel like translators, proofreaders, editors into the sphere. As a result, there published 47 kinds of books on the 212,75 printed sheet in 83,5thousand copies in 1935, and in 1940 there published 100 kinds of books on 608 sheet in 513 thousand copies. In 1933-1934 there published 8 course books in the karakalpak language, but till 1939 all the course books in the karakalpak language were published in the printing houses of the Russian Federation People's Enlightenment Commissariat "Uchpedgiz". The reason of it lied not only in shortage of qualified personnel and weak poligraphic base, but in state policy of centralizing the system of education and enlightenment. That's why the Karakalak Publishing House printed only political, literary, agricultural, and methodological books (Central State Archive of the Republic of Karakalpakstan, stock.323, register.1, file.7, paper.13) But in 1940 the Karakalak State Publishing House printed only course books in 54 titles and in 1941 all the course books in the karakalpak language were published here in the Cyrillic alphabet.

In the 1930s the policy of developing the people's habit of reading was realized in the form of "culture campaign", which aimed to implement the idea of enlightening and educating everybody, in correlation to other social and political campaigns like liquidation of illiteracy, women movement, antireligious struggle and others. The publication of books was also ruled in the frame of this policy, paying more attention to the theme of books, enlarging the number of publications in the karakalpak language, printing more republican and regional newspapers, involving more and more young poets and writers, active national intelligentsia. We can name the karakalpak state and social activists in this sphere like K.Avezov, S.Majitov, I.Fazilov, T.Safiev, O.Kojurov, P.Seytmuratov, M.Yakubov, K.Ayimbetov and others.

All the printed works served for agitation and propaganda of the Communist Party's work, and also answered the needs of karakalpak society in utility knowledge. As we mentioned above, the Karakalak State Publishing House printed only political, literary, agricultural, and methodological books in limited copies, and the most part of the publications consisted of books in Russian, uzbek and 
Kazakh languages. The Personnel of the Publishing House in 1939 consisted of 19 people, 9 of which were engaged into translations of political and agitation and propaganda texts from the Russian language and publication of them. The course books in the karakalpak language were still published in Moscow and Tashkent Publishing Houses. There worked a staff consisted of the karakalpak educated people, (In Moscow- 7 people, in Tashkent - 5) (Central State Archive of the Republic of Karakalpakstan, stock.323, register.1, file.7, paper.13-14).

Motivating to learn. In 1930s not only the publication process, but also the system of distributing the printed products began to improve; various books, brochures, newspapers and magazines were produced, different kind of republican and regional conferences, meetings, trips and other cultural events were held. There appeared small houses- reading rooms and libraries, though most of them were situated in inconvenient places and did not work regularly. Though the publication business was considered by the Communist Party as one of the main sphere of "ideological front" and as a tool for agitation and propaganda work, in the condition of Karakalpakstan it was impossible, as the mass did not buy them. As an example we can give the fact that the newspaper "The Karakalpak Communist" was only subscribed by the members of the Party and some intelligentsia. Most of the writers and poets did their best in developing population's motivation to read. For example, a famous poet-enlightener S. Majitov in his poem invited everybody to learn, to be a knowledgeable person.

"Ей, жарандар, бізмұндамыз,

Қосылайық, оқуғакел,

Барбілімдіоқып, ұғып,

Көңілгеәбдентокуғакел," (Majitov, 1975: 96)

The poet Khojahmet Ahis poem «Білімменжансыншам» (1931) also mentions the value of knowledge, that everything depends on the science and learning:

Қарағым, оқы, білімал,

Оқымағанадамлал.

Күллі ісоқу-білімде,

Оқуоқы, оқу - мал..., (Axmetov, 1975: 77)

One more peculiar features of that time was the high censorship, or paying more attention to the ideology of the printed materials. There was a special department, the department on literature and publication under the People's Commissariat of Enlightenment ("Glavlit"), which was responsible for political-ideological content of publications. The authorized people of the above mentioned department worked in local publishing houses, editorial offices and printing places. (Nurjanov, 2016: 38)

Conclusions. In whole, the publication sphere in Karakalpakstan was just being organized in 1930s: they were strengthening the financial and technical base of the sphere and at the same time supplying the branch with qualified specialists and personnel. But still there was the process of centralizing the sphere, as the political, economic, industrial and staff policy was ruled by the Center, they followed the planning of the Center. The government took all the responsibility of financing this sphere, directed the process of publication, delivering and selling the printed products, organizing the unique system of the management. The following system let the ideological points of the soviet union root in the minds of karakalpak people and helped the totalitarian system to rule the society.

\section{REFERENCES}

1. Abduazizova N. (2008) Milliy jurnalistika tarihi. Birinshi jild. [The history of national journalism. Volume 1]. Toshkent, p.12.

2. Ayimbetov K., (2008) Otken kunnen elesler. [Flashback to past]. Nukus. p.71

3. Axmetov Kh. (1975) Shigarmalari [Creations]. Nukus. p.77

4. Central State Archive of the Republic of Karakalpakstan, stock.323, register.1, file.7, paper.13-14

5. Dosumov Ya. (1960) Ocherki istorii Karakalpakskoy ASSR [Sketches about the history of Karakalpak ASSR]. Tashkent.

6. Majitov S. (1975) Shigarmalari [Creations]. Nukus. pp. 96-97

7. Nurjanov S. (2015) Periodicheskaya pechat Karakalpakstana v sisteme obshestvennix otnoshenii [The Periodicals of Karakalpakstan in the system of social relations]. Nukus. p.11.

8. Nurjanov S. (2016) Pressa Karakalpakstana 30x godov XX veka I massovoe soznaniye [The Press of Karakalpakstan in 30s of the XX century and mass recognition] O'zbekiston tarixi, no1. p.38.

9. QzilQaraqalpaqbstan, 1935, March. 
10. Semenov I. (1971) O zarojdenii karakalpakskoy sovetskoy pechati. [About the formation of karakalpak soviet publication] Vestnik of Karakalpak branch of Uzbekistan SSR Academy of Sciences, no 4.

11. Shalekenov U. (1960) Ocherki po istorii kulturi Sovetskoy Karakalpakii (1917-1940) [Sketches on the history of the Soviet Karakalpakstan Culture (1917-1940)]. Nukus.

12. Syinov U. (1964) Knigopechatanie v Karakalpakii [The Book Publication in Karakalpakiya]. Vestnik of Karakalpak branch of Uzbekistan SSR Academy of Sciences, no1.

13. Syinov U. (1962) Periodicheskaya pechat Karakalpakskoy avtonomnoy oblasti [The Periodicals of Karakalpak autonomous republic]. Vestnik of Karakalpak branch of Uzbekistan SSR Academy of Sciences, no3;

14. Yusupov O., Kalimbetov A. (1993) Karakalpakstan baspasina 60 jil. [60 years to Karakalpakstan Publishing House]. Nukus. pp.15-16.

15. http://coolreferat.com/ 